\title{
Irrawaddy dolphin Orcaella brevirostris in the Cambodian Mekong River: an initial survey
}

\author{
Ian G. Baird and Isabel L. Beasley
}

\begin{abstract}
Irrawaddy dolphins Orcaella brevirostiris are found in coastal waters from the Bay of Bengal east to Palawan, Philippines and south to northern Australia. They also occur in three large tropical river systems in South-east Asia: the Mekong, Mahakam and Ayeyarwady. In March and May 1997 approximately $350 \mathrm{~km}$ of riverine habitat in parts of north-east Cambodia were surveyed, discussions took place with local people, and reported dry season dolphin habitat was mapped. Our objectives were to investigate the status, habitat and distribution of dolphins in north-east Cambodia and identify threats to the continued survival of dolphins in the Mekong River Basin. Nine groups of dolphins were observed in the Mekong River. A 'best' estimate of 40 animals were seen. Irrawaddy dolphins were generally confined to sections of the river with water levels $>8-10 \mathrm{~m}$ during the dry season. It appears that the Mekong River dolphin population is rapidly
\end{abstract}

declining. In 1997 there were probably no more than 100-150 dolphins left in north-east Cambodia (including southern Laos) and no more than 200 within the entire Mekong River Basin, although these numbers remain tentative. Anthropogenic mortality is high, albeit largely unintentional, and there is considerable risk that the dolphin population will become locally extinct in the Mekong River in the near future. The establishment of community-managed deep water Fish Conservation Zones with government support may represent the best opportunity for reducing dry season dolphin mortality from large-meshed gillnet entanglement. Efforts to establish protected areas for dolphins are currently underway.

Keywords Cambodia, Cetacea, Irrawaddy dolphin, fish conservation zones, fisheries co-management, Laos, Mekong River, Orcaella brevirostris.

\section{Introduction and background}

The Irrawaddy dolphin Orcaella brevirostris is found in the tropics and subtropics, distributed from the Bay of Bengal east to Palawan, Philippines and south to northern Australia. It is known from a variety of habitats, including coastal marine, estuaries, brackish waters and freshwater rivers. The large river systems inhabited by the species are the Ayeyarwady (Myanmar), Mahakam (Indonesia) and Mekong (southern Laos, Cambodia and Vietnam) Rivers (Stacey \& Leatherwood, 1997).

Irrawaddy dolphins occur to a maximum of $722 \mathrm{~km}$ up the Mekong River to the Khone Falls $(<1 \mathrm{~km}$ north from the Lao/Cambodian border); the falls are a natural

Ian G. Baird ${ }^{1}$ (Corresponding author) Department of Geography, The University of British Columbia, Vancouver, Canada. E-mail ianbaird@shaw.ca

Isabel L. Beasley² School of Tropical Environment Studies and Geography, James Cook University, Townsville, Australia.

${ }^{1}$ Also at: Global Association for People and the Environment (GAPE), P.O. Box 860, Pakse, Lao PDR.

${ }^{2}$ Also at: Mekong Dolphin Conservation Project, PO Box 9123, Kratie, Cambodia.

Received 29 September 2003. Revision requested 19 January 2004. Accepted 26 January 2005. biogeographical barrier to dolphin movement north, as well as to movements of some fish species (Baird \& Mounsouphom, 1994; Roberts \& Baird, 1995). The dolphins also historically occurred in the Sekong River (a river branching off the mainstream Mekong at Stung Treng town) as far upriver as Kaleum District, Sekong Province, southern Lao PDR, which is approximately $950 \mathrm{~km}$ from the South China Sea (Baird \& Mounsouphom, 1994, 1997) (Fig. 1).

A number of anthropogenic causes of mortality to Irrawaddy dolphins in the Mekong River basin have previously been identified, including accidental entanglement in large-meshed gillnets and unintentional killing by explosives used for fishing (Baird \& Mounsouphom, 1994, 1997). Between December 1990 and September 1998, 27 dead dolphins were either found by researchers, or reliably reported to them, along the $<10 \mathrm{~km}$ stretch of the Mekong River that constitutes the international border between Laos and Cambodia. Most dolphin mortality was human induced, albeit unintentionally. These statistics support observations and reports from fishers that the Mekong River Irrawaddy dolphin population (at least on the Lao/Cambodian border and Sekong and Sesan River systems) is in serious decline and urgently requires protection (Baird \& Mounsouphom, 1994, 1997; Stacey, 1996). 


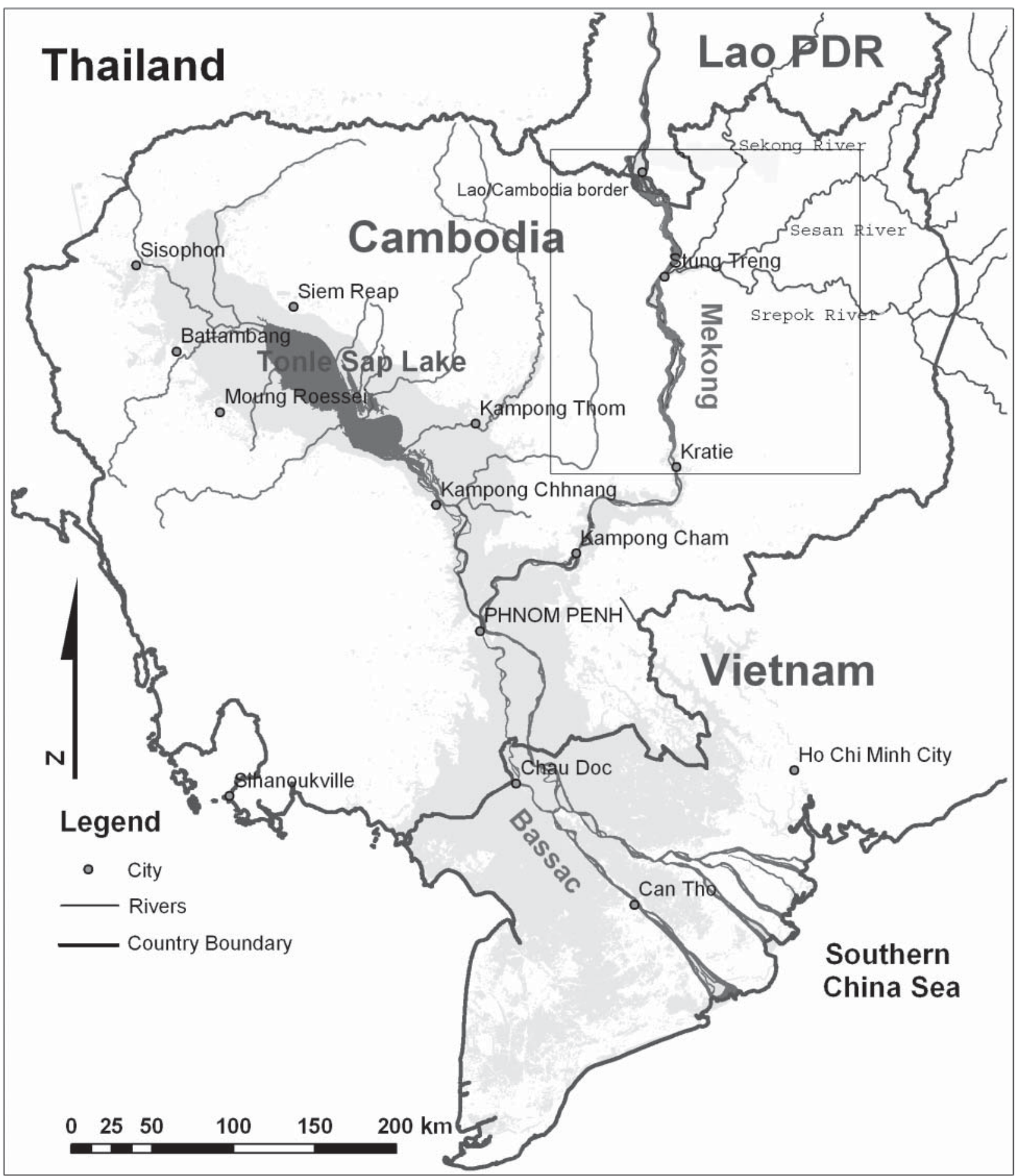

Fig. 1 Cambodia, with major rivers mentioned in the text. The rectangle indicates the area of Fig. 2.

In 1997 we conducted surveys and interviews in the Mekong, Sekong and Sesan Rivers in north-east Cambodia to investigate (1) the status, habitat and distribution of the Irrawaddy dolphin, (2) threats to the continued survival of this species, and (3) potential options for improving the management and conservation of Irrawaddy dolphins. These surveys provided the first assessment of the status of the Irrawaddy dolphin in Cambodian Mekong River waters. Here we describe these surveys and examine the causes of decline of this river dolphin population. The Mekong Dolphin Conservation Project is presently conducting further research on this dolphin population and initiating various conservation and awareness raising activities. 


\section{Study area}

The study area included the Mekong River from the Lao/Cambodian border (the northern extent of the dolphin's distribution in the Mekong River) downriver to the provincial capital of Kratie, in north-east Cambodia, along the Sekong River in Stung Treng Province up to the Lao border, and up the Sesan River to the confluence of the Srepok and Sesan Rivers (Fig. 1). Parts of the Sesan River upstream from the border between Ratanakiri and Stung Treng Province were not surveyed, as the Sesan River in Ratanakiri Province had been previously investigated (Baird, 1995). We did not investigate the Srepok River, as local people told us that dolphins had not been seen in the river since 1985. All the habitat surveyed consisted of large perennial rivers characterized by periodic rapids and deep water pools; the river-bed also supports significant tracts of seasonally inundated forests. The Mekong River south of Kratie was not surveyed because the nature of the river changes c. $15 \mathrm{~km}$ north of Kratie. Below that location there are few rock formations in the river, resulting in a lack of rapids, deep water pools and seasonally inundated forests, which are all common up-river from Kratie. Previous interview surveys with Cham fishers in Kampong Cham Province in 1993 indicated that dolphins only move south of the deep water habitats north of Kratie in the wet season (IGB, unpubl. data). Therefore, it was not considered a priority to survey the area during these dry season surveys.

\section{Methods}

Surveys, interviews and discussions were carried out in March and May 1997 (the dry season) by IGB.

\section{Interviews and discussions}

Data were collected from villagers through semistructured interviews and informal discussions. IGB conducted all the interviews, in Lao, in Lao speaking communities. A local Khmer colleague conducted all interviews in Khmer speaking areas. These interviews served two primary purposes: to assess potential suitable dry season dolphin habitat to facilitate boat surveys, and to obtain information regarding the knowledge of local people in relation to dolphin status, distribution, mortality and their perceptions of other components of the dolphin's aquatic habitat.

\section{Boat surveys}

Because the dolphins have a clumped distribution in dry season deep water habitats (Baird \& Mounsouphom, 1997), we estimated abundance of dolphins in the survey area following the reasoning for estimating the absolute abundance of Asian river dolphins (Smith \& Reeves, 2000), but with an adjusted survey protocol. Security at the time of fieldwork influenced the implementation of surveys, as the Khmer Rouge was still active. It was impractical to slowly conduct transects along remote sections of river and therefore some small sections of the Mekong River in Kratie Province were not surveyed. Rapidly changing geomorphology and hydrological conditions also prevented random search patterns.

Surveys were conducted with at least three observers. The front two observers covered 180 degrees in front of the boat. The third observer monitored the 180degree area behind the boat. Observers rotated regularly between using binoculars and the naked eye. All surveys were conducted using small, canoe-like boats with 8-11 horsepower long-tailed motors that provided a viewing height of $1 \mathrm{~m}$ above the water surface. Boats moved at moderate and variable speeds while out of potential dolphin habitat (determined from interview data). When in suspected dolphin habitat (such as deep water pool areas), boat engines were stopped. Stop durations of 10 minutes were chosen because maximum dive times are between 3 minutes 20 seconds (Stacey \& Leatherwood, 1997) and 7 minutes 11 seconds (Stacey, 1996). The boat engine was stopped because the sound of boat engines increases dive times and causes dolphins to move away (Stacey, 1996). It is also usually easier to hear dolphin respirations than see them when stopped (Baird \& Mounsouphom, 1994; Stacey, 1996; Smith \& Reeves, 2000). After 10 minutes the boat would move ahead 500 $\mathrm{m}$ to search again. Observations for dolphins continued even when outside potential habitat.

When a dolphin group (defined as any number of dolphins observed swimming near each other at the time of observations) was sighted, the boat would observe the group for a minimum of 20 minutes. Data were collected on group size, composition, location and water depth. Depth was determined based on reports from local fishers, and was converted from local measurements to metres. During studies at the Lao/Cambodian border Stacey (1996) confirmed the accuracy of reports from local fishers of dry season depth.

Methodology to estimate group size was adopted from Smith \& Reeves (2000), which consisted of recording a high estimate (maximum number of dolphins in the group), a best estimate (the estimate observers were most confident of) and a low estimate (the minimum number of dolphins in the group). This methodology has been adopted by cetacean researchers because it is often impossible to be certain of the number of dolphins in a sighting, and thus presents data in a way that makes potential errors more transparent. We are confident that none of the dolphins were double counted, as groups 
were either seen many $\mathrm{km}$ from each other or were identified, via dorsal fin observations, as including different individuals.

\section{Results}

\section{Interviews}

Villagers reported a total of 36 locations of historical dry season dolphin habitat: four in the Sesan River, nine in the Sekong River, and 23 in the Mekong River (Table 1, Fig. 2). In the Sesan River there are only a few dolphins in the Anlong Chan/Anlong Man area, just downstream from the confluence of the Srepok and Sesan Rivers (site \#13). Anlong Katuk (site \#10) is the farthest deep water pool up the Sesan River that dolphins historically inhabited during the dry season. In the dry season, dolphins are apparently not able to pass the Sesan River's Tha Da rapids, which are situated a few $\mathrm{km}$ upstream from the confluence of the Srepok and Sesan Rivers.

It was reported that there are no dolphins resident during the dry season in the Srepok River but, before 1985, they were occasionally found in the wet season. From reports and observations it appears that dolphins no longer inhabit the Sekong River in the dry season (although they were found there before 1970) and some still ascend the river as far as Laos in the wet season (Baird \& Mounsouphom, 1997).

Almost all of the remaining dolphins in north-east Cambodia inhabit deep water areas in the mainstream Mekong River (from $15 \mathrm{~km}$ north of Kratie to the Lao/ Cambodian border) during the dry season. However, a number of deep water pool areas reported by local villagers to have been dry season dolphin habitat have apparently not been inhabited by dolphins for decades.

Fishers claim that there are no dry season groups of dolphins south of Kratie in the mainstream Mekong River to at least Phnom Penh. Ethnic Cham fishers from Kampong Cham Province (50 km south of Kratie) interviewed by IGB in 1993 supported this conclusion. Local people believe the dolphins disperse south, to at least as far as Phnom Penh, during the wet season, before returning to Kratie and Stung Treng Provinces during the dry season.

Many dolphins reportedly died in the late 1990s (Table 2). Most were apparently entangled in largemeshed gillnets. It appears that such nets pose the greatest threat to dolphins. Gillnetting throughout the study area increased markedly during the 1990s (IGB, pers. obs., 2000).

\section{Boat surveys}

A total of $350 \mathrm{~km}$ of surveys were undertaken, $193 \mathrm{~km}$ in the mainstream Mekong River between the Cambodian/ Lao border and Kratie town, 110 km in the Sekong River between Yang Soum village and Stung Treng town (located at the Sekong River's confluence with the Mekong River), and $47 \mathrm{~km}$ in the Sesan River between Sreko village, Sesan District, Stung Treng Province and the Sesan River's confluence with the Sekong River. A total of nine groups of dolphins were sighted, all in the mainstream Mekong River (Table 3; Fig. 2). The best estimate of numbers observed was 40 individuals, with a range of 32-49. Average group size was 4 individuals (range 1-9). The primary habitat for the observed dolphins was areas with water $>8 \mathrm{~m}$ deep. The dolphins appear to prefer areas where convergent streams or other secondary currents have created eddy counter current systems in the mainstream flow.

\section{Discussion}

The majority of Irrawaddy dolphins in the Mekong River basin are in Cambodia riverine waters. A few $\mathrm{km}$ up the Mekong River from the Lao/Cambodian border a series of large waterfalls and rapids (Khone Falls) act as a barrier and dolphins have never been known to inhabit the Mekong River above these (Baird \& Mounsouphom, 1997). The best estimate for the number of dolphins observed during the 1997 surveys was 40 individuals. Based on direct counts, interviews and habitat considerations, it seems likely that in 1997 there were no more than 100-150 Irrawaddy dolphins in north-east Cambodia (including the group found on the Lao/Cambodian border, southern Laos). However, these estimates are tentative and further research is required to refine them. Apart from the group of dolphins observed along the Lao/Cambodian border, there are no other resident dolphin populations in Laos (Baird \& Mounsouphom, 1997).

The only published records of dolphins inhabiting the Mekong River in Vietnam are from Lloze (1973). IGB conducted extensive interviews with fishers living along the Mekong River in Vietnam in 1992. All interviewees reported that dolphins had disappeared from this section of the Mekong River by the end of the 1970s, except for the rare occurrence of individual animals for short periods of time. In addition, a total of $224 \mathrm{~km}$ of survey effort in the Vietnamese Mekong River in April 1996, covering the majority of large channels between Can Tho and An Phu (Hau Giang Distributary) and between Tan Chau and Sa Dec (Tien Giang Distributary), failed to sight any Irrawaddy dolphins, with war-related mortality, accidental catch in fishing nets, and/or depletion of their food cited as possible causes (Smith et al., 1997). In March 2002 a single Irrawaddy dolphin carcass was found in a fishing net in the Tien tributary, near the Vietnam/ Cambodian border (Chung \& Ho, 2002). However, this is the only known report since those of Lloze (1973) and 


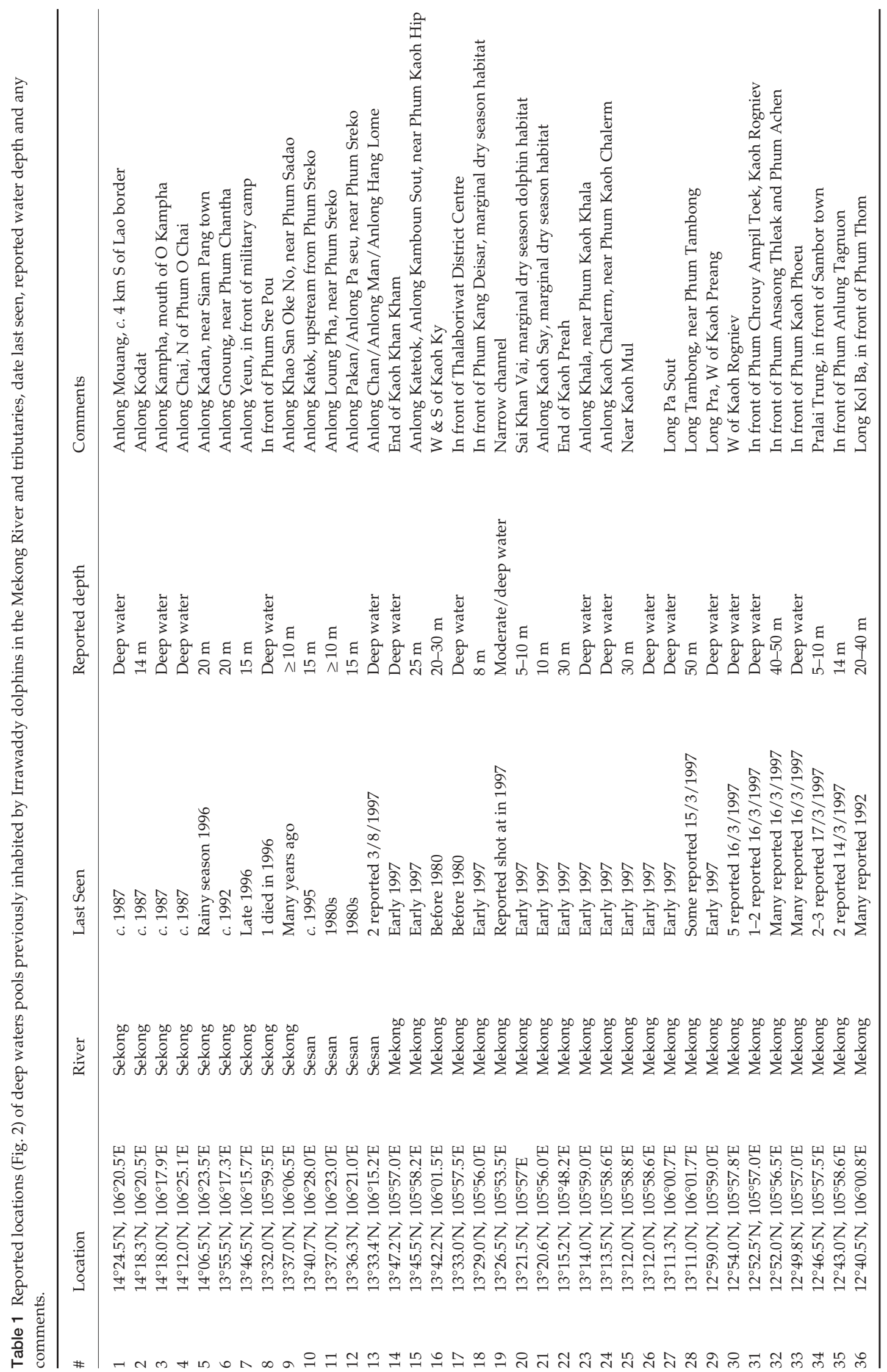




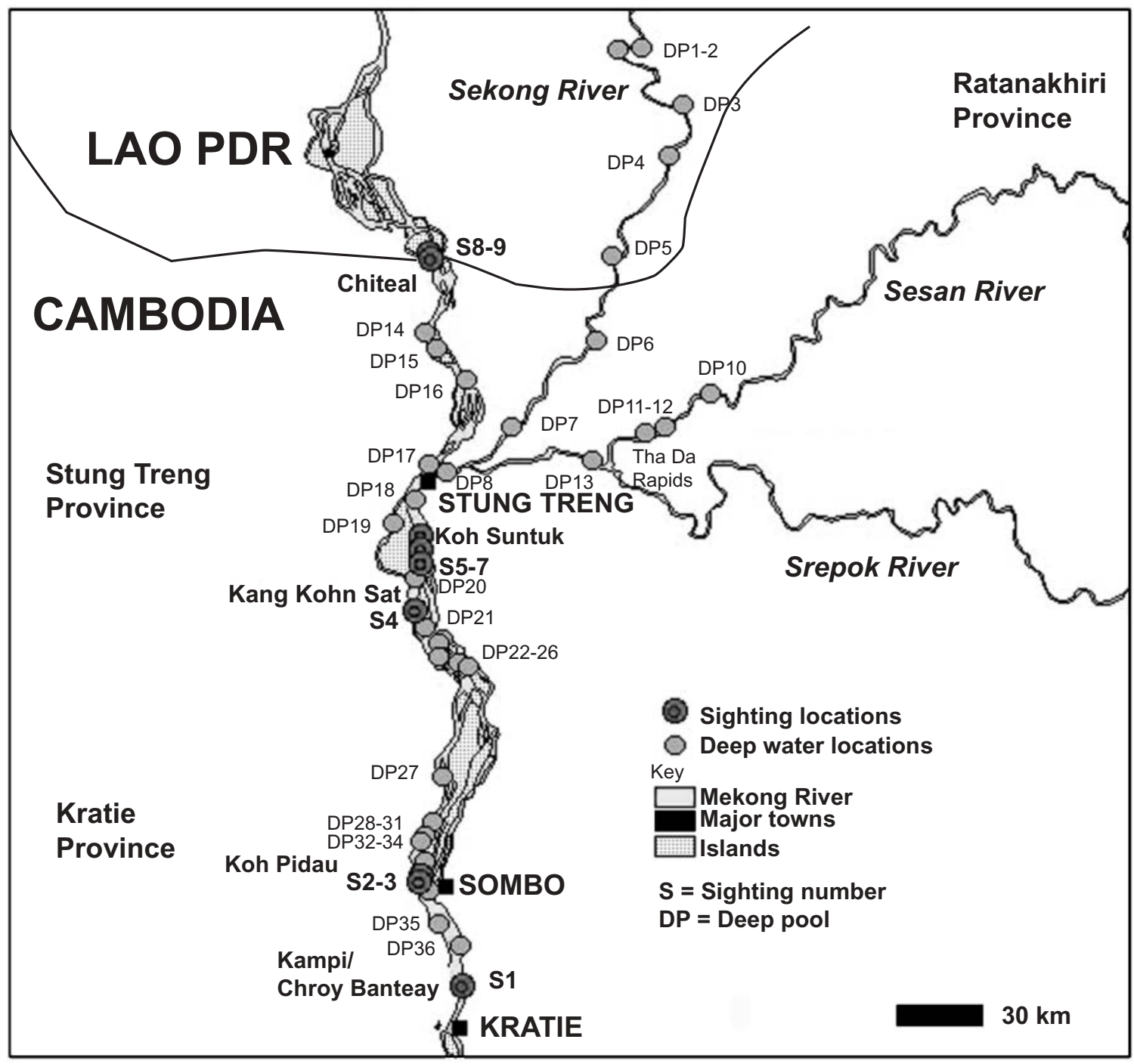

Fig. 2 The study area (location indicated by rectangle in Fig. 1) along the Mekong River and tributaries, with deep water pools in which Irrawaddy dolphins were previously known (numbered locations in Table 1) and sightings in 1997 (numbered locations in Table 3).

probably represents a vagrant record. It therefore seems unlikely that there are any resident dolphin populations in the Mekong basin in Vietnam.

While there may be a small population of dolphins in the Mekong River between Phnom Penh and the Vietnamese border, it seems highly unlikely that there are more than c. 20 individuals, based on infrequent reports of dolphins by local people and the lack of favourable dolphin habitat. This would result in the total Irrawaddy dolphin population in the Mekong River basin, in 1997, being $<200$. It is unlikely that there is any interaction between the remaining dolphins in the Mekong River basin (Cambodia and southern Laos), and Irrawaddy dolphins in the South China Sea and Vietnamese delta. This conclusion is based on the heavy human use of parts of the Mekong River in Vietnam (where dolphins have not been seen by local people since the 1970s), which would probably deter any dolphin movement south to the Delta.

Based on interviews and surveys it appears that there are no longer any dolphins inhabiting the Sekong River in the dry season, although some still ascend the river as far as Laos in the wet season, and they sometimes move up small tributaries during the rainy season (Baird \& Mounsouphom, 1997). The presence of dolphins in the Sesan River was investigated in 1995 (Baird, 1995) and no dolphins have been reported from the upper reaches of the Sesan or Srepok Rivers in Ratanakhiri Province, north-east Cambodia since 1985. Dolphins were never common in the middle Sesan and historically only ever moved up-river during the wet season, for short periods of time.

Hunting for dolphin oil in the mid 1970s by the Khmer Rouge resulted in the decimation of dolphins inhabiting 


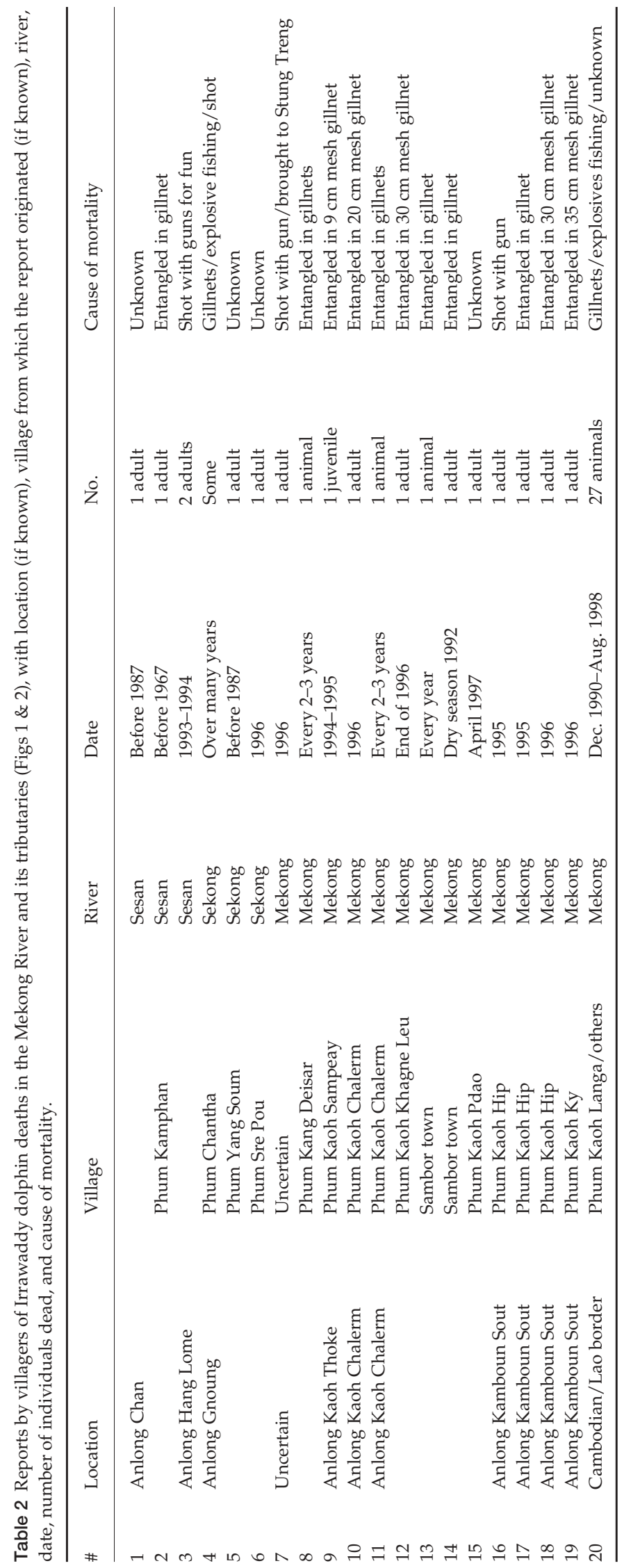




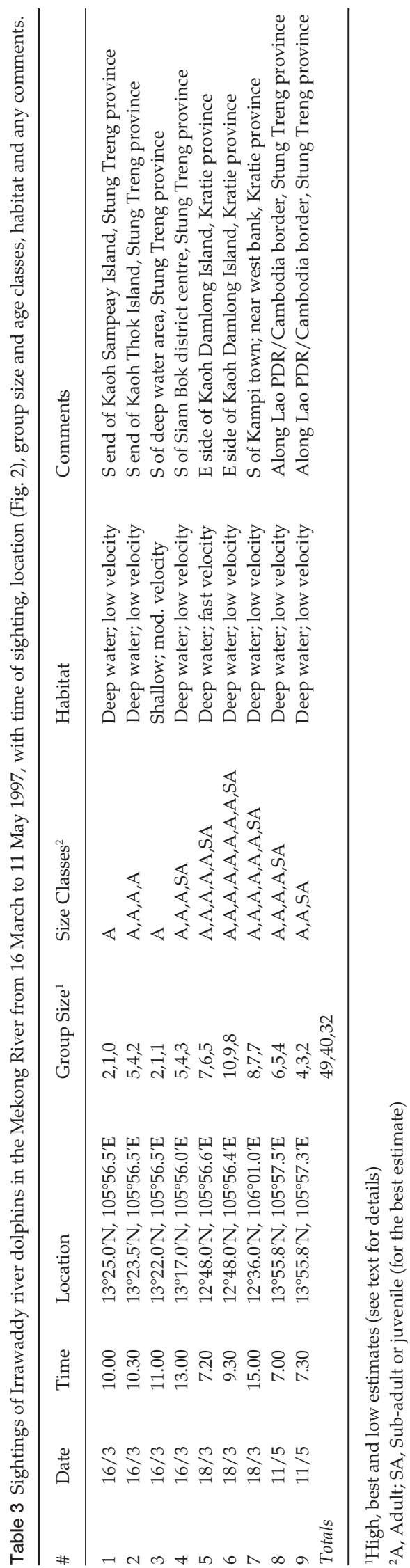


Cambodia's Tonle Sap Great Lake. Dolphins were shot, hung in the sun, and oil collected in pails under the carcasses was then used as a petroleum substitute for motorcycles and motorboats (Touch Seang Tana, pers. comm., 1995; villagers living adjacent to the Great Lake, pers. comm., December 1995). As of 1997 only a few small groups of dolphins were reported to be occasionally seen in the Great Lake and other provinces bordering the Lake and Tonle Sap River (Nao Thouk pers. comm., 1997; Touch Seang Tana, pers. comm., 1997; Siem Riep villagers, pers. comm., 1995).

Habitat availability is important for the Mekong River Irrawaddy dolphins in the dry season (December to early May). While dolphins make use of many parts of the river (including river branches and small streams) during the high-water season (June-November; Baird \& Mounsouphom, 1997), available dolphin habitat in the dry season is greatly reduced. This makes locating and observing dolphins much easier during this season (particularly at its height during April/May).

During the dry season many fish, including most large species, move into deep water areas (Baird et al., 2001; Poulsen, 2001; Baird \& Flaherty, 2004). This is significant because dolphins in the Mekong River appear to spend most of their dry season day feeding (Stacey, 1996). Irrawaddy dolphins along the Lao/Cambodian border were seen most frequently in waters of 15-19.9 m depth during the dry season (Stacey, 1996). Findings by Stacey (1996) and our personal observations indicate that during the dry season dolphins only rarely venture into water depths $<9 \mathrm{~m}$.

The long-distance movements of schools of small cyprinids up the Mekong River probably influences the habitat usage and feeding patterns of dolphins in the dry season (Baird \& Mounsouphom, 1994; Baird et al., 2003). Baird \& Mounsouphom (1997) found the remains of 10 whole Henicorhynchus (reported to be Cirrhinus at the time) lobatus in the stomach of a dead dolphin recovered from the Mekong River near the Lao/Cambodia border in March 1995.

Irrawaddy dolphins from the Ayeyarwady River in Burma engage in cooperative fishing activities with village fishers (Smith \& Hobbs, 2002). Fishers from Kaoh Hip village, Thalaboriwat District, Stung Treng Province, reported that dolphins are beneficial to their fishing activities. They claimed that the dolphins commonly chase fish into small-meshed gillnets set in shallow waters near the deep water area called Anlong Kamboun Sout. However, they do not believe that dolphins intentionally help fishers. Lao fishers from Hang Sadam village, near the Khone Falls in southern Laos, have made similar claims about dolphins 'chasing fish into set gillnets' (Villagers in southern Laos, pers comm., 1993).
With a high mortality rate and small population, the Irrawaddy dolphin population in north-east Cambodia (and ultimately the entire Mekong River Basin) is in decline. Although fishers do not want to catch dolphins in large-meshed gillnets, and it seems likely that dolphins can detect large and small-meshed gillnets in the water (Baird \& Mounsouphom 1997), gillnet entanglement appears to be the main current cause of mortality. Many deep water areas that were previously inhabited by dolphins year-round have reportedly not been inhabited for decades. Villagers living next to major rivers in north-east Cambodia are familiar with dolphins and mostly respect them, as also noted by Baird \& Mounsouphom (1994) and Lloze (1973). It is therefore ironic that the Mekong River Irrawaddy dolphin population is suffering a dramatic decline because of unintentional human-induced mortality.

Dolphins are also faced with potentially lethal impacts from two proposed large hydroelectric dams: one on the mainstream Mekong River just north of Stung Treng, and the other upstream of the town of Sambor, Kratie Province (Mekong Secretariat, 1995). These dams, if built, would both separate and isolate the remaining dolphin population, further reducing the available gene pool for dolphin reproduction, and potentially catalyse local extinction of the Mekong River Irrawaddy dolphin population. Mekong River fish stocks (essential for both dolphins and local villagers) would also be negatively affected. In addition, the Lower Srepok 2 and the Lower Sesan 2 dams, proposed for lower sections of both rivers in Stung Treng Province (ADB, 1998; Baird \& Flaherty, 2004) and the Mekong River Khone Falls and Tonle Sap River dams all pose threats to the dolphins (Baird \& Mounsouphom, 1997).

One conservation option for the Mekong River Irrawaddy dolphins is to protect prime deep water dry season dolphin habitat as Fish Conservation Zones in order to stop or reduce gillnet use in these key areas. Such Zones have been established by 63 villages in Khong District, Champasak Province, southern Laos, and although these are outside dolphin habitat above the Khone Falls, they have apparently been successful in increasing the stocks of certain fish species (Baird et al., 2001; Baird \& Flaherty, 2005). Fish Conservation Zones in north-east Cambodia could benefit both fish stocks and dolphins. However, experiences in Laos indicate that these Zones will only be effective when both government agencies and local communities are supportive (Baird \& Flaherty, 2005). Villagers in many parts of Stung Treng Province were receptive to the idea of establishing Fish Conservation Zones, and efforts are presently being made to establish protected areas for the dolphins. Protecting the dolphin habitat that straddles Cambodia and Laos is particularly challenging because of the transboundary nature of this habitat. 
These surveys provide the first detailed information about the status and distribution of Irrawaddy dolphins in north-east Cambodia. Additional work is presently being conducted by the Mekong Dolphin Conservation Project, a collaborative project between James Cook University, Australia, and the Cambodian Department of Fisheries, to update information on the dolphin's status and promote its conservation. This includes conducting further dolphin population surveys throughout the entire Cambodian and Vietnamese Mekong River, raising local and government awareness about the need to protect the dolphins, and providing alternative livelihood options for local people living near critical dolphin habitats. In addition, the Cambodia Department of Fisheries is in the process of designating dolphin/fisheries protected areas covering critical dolphin habitats. Designation and management of these protected areas would ideally follow that of the Fish Conservation Zones in Laos, with full community and government support.

\section{Acknowledgements}

Our thanks to the Whale and Dolphin Conservation Society, UK, who funded this study, Mr. Matti Kummu, Tonle Sap Modelling Project, who assisted with the preparation of Fig. 1, and two anonymous reviewers whose comments greatly improved the manuscript.

\section{References}

Asian Development Bank (1998) Sekong - Sesan and Nam Theun River Basins Hydropower Study: Interim Report, Volume 1. Sir William Halcrow and Partners Ltd in association with EPDC International \& MK Centennial, Manila, Philippines.

Baird, I.G. (1995) A Rapid Study of Fish and Fisheries and Livelihoods and Natural Resources along the Sesan River, Ratanakiri, Cambodia. Unpublished Livelihoods and Natural Resources Study Report, Oxfam, UK and Ireland \& Novib, Ban Lung, Ratanakiri, Cambodia.

Baird, I.G. \& Flaherty, M.S. (2004) Beyond national borders: important Mekong River medium sized migratory carps (Cyprinidae) and fisheries in Laos and Cambodia. Asian Fisheries Science, 17, 279-298.

Baird, I.G. \& Flaherty, M.S. (2005) Mekong River fish conservation zones in southern Laos: assessing effectiveness using local ecological knowledge. Environmental Management, 35, 1-17.

Baird, I.G., Flaherty, M.S. \& Phylavanh, B. (2003) Rhythms of the river: lunar phases and small cyprinids migrations in the Mekong River. Natural History Bulletin of the Siam Society, 51, 1-32.

Baird, I.G. \& Mounsouphom, B. (1994) Irrawaddy dolphins (Orcaella brevirostris) in southern Lao PDR and northeastern Cambodia. Natural History Bulletin of the Siam Society, 42, 159-175.

Baird, I.G. \& Mounsouphom, B. (1997) Distribution, mortality, diet and conservation of Irrawaddy dolphins (Orcaella brevirostris Gray) in Lao PDR. Asian Marine Biology, 14, 41-48.

Baird, I.G., Phylavanh, B., Vongsenesouk, B. \& Xaiyamanivong, K. (2001) The ecology and conservation of the small-scale croaker Boesemania microlepis (Bleeker 1858-59) in the mainstream Mekong River, southern Laos. Natural History Bulletin of the Siam Society, 49, 161-176.

Chung, B.D. \& Ho, D.T. (2002) A Review of the Results of the Studies on Marine Mammals in Vietnamese Waters.

Unpublished Report submitted to the Workshop on the Biology and Conservation of Small Cetaceans and Dugongs of Southeast Asia, Silliman University, Dumaguete City, Philippines, 24-26 July, 2002.

Lloze, R. (1973) Contribution a l'etude anatomique histologique et biologique de l'Orcaella brevirostris (Gray, 1866) (Cetacea, Delphinidae) du Mekong. PhD thesis, L'Universite Paul Sabatier de Toulouse, France.

Mekong Secretariat (1995) Mekong Mainstream Run-of-River Hydropower. Mekong Secretariat, Bangkok, Thailand.

Poulsen, A.F. (2001) Deep Pools as Dry Season Fish Habitats in the Mekong River Basin. Report to the Assessment of Mekong Fisheries Component, Mekong River Commission, Vientiane, Lao PDR.

Roberts, T.R. \& Baird, I.G. (1995) Traditional fisheries and fish ecology on the Mekong River at Khone Waterfalls in southern Laos. Natural History Bulletin of the Siam Society, 43, 219-262.

Smith, B.D. \& Hobbs, L. (2002) Status of Irrawaddy dolphins Orcaella brevirostris in the upper reaches of the Ayeyarwady River, Myanmar. Raffles Bulletin of Zoology, Supplement, 67-73.

Smith, B.D., Jefferson, T.A., Leatherwood, S., Ho, D.T., Thuoc, C.V. \& Quang, Le Hai (1997) Investigations of marine mammals in Vietnam. Asian Marine Biology, 14, 145-172.

Smith, B.D. \& Reeves, R. (2000) Survey methods for population. Assessment of Asian River Dolphins. Environmental Conservation, 3, 341-350.

Stacey, P.J. (1996) Natural history and conservation of Irrawaddy dolphins, Orcaella brevirostris, with special reference to the Mékong River, Lao PDR. MSc thesis, University of Victoria, Canada.

Stacey, P.J. \& Leatherwood, S. (1997) The Irrawaddy dolphin, Orcaella brevirostris: a summary of current knowledge and recommendations for conservation action. Asian Marine Biology, 14, 105-214.

\section{Biographical sketches}

Ian G. Baird conducted the first studies of Irrawaddy dolphins in Laos in 1991. In 1993 he founded the Lao Community Fisheries and Dolphin Protection Project, and during 1997-1999 he was the Aquatic Resource Management and Community Development Specialist for the Environmental Protection and Community Development in Siphandone Wetland Project. He has also conducted studies of fish and fisheries in the Mekong basin, and was the first researcher to endorse community ideas to protect deep water parts of the Mekong River as Fish Conservation Zones.

Isabel L. Beasley has researched cetaceans in Asia since 1997. She founded the Mekong Dolphin Conservation Project in Cambodia in 2001 and continues to coordinate project activities. Her primary focus is research, conservation and management of the Mekong dolphin population, while attempting to emphasize local community management and perspectives. 